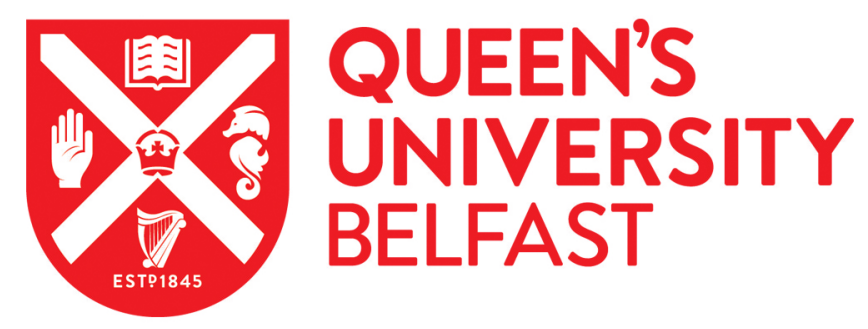

\title{
The Extra-territorial Obligations of European States regarding Human Rights in the Context of Terrorism
}

Dickson, B. (2016). The Extra-territorial Obligations of European States regarding Human Rights in the Context of Terrorism. In F. Fabbrini, \& V. Jackson (Eds.), Constitutionalism Across Borders in the Struggle Against Terrorism (pp. 213-232). Edward Elgar Publishing.

Published in:

Constitutionalism Across Borders in the Struggle Against Terrorism

Document Version:

Peer reviewed version

Queen's University Belfast - Research Portal:

Link to publication record in Queen's University Belfast Research Portal

Publisher rights

(c) 2016 The Editors

This is a draft chapter / article. The final version is available in [insert book title] edited by [insert editor(s) or author(s)], published in 2016 by Edward Elgar Publishing Ltd. The material cannot be used for any other purpose without further permission of the publisher, and is for private use only.

\section{General rights}

Copyright for the publications made accessible via the Queen's University Belfast Research Portal is retained by the author(s) and / or other copyright owners and it is a condition of accessing these publications that users recognise and abide by the legal requirements associated with these rights.

Take down policy

The Research Portal is Queen's institutional repository that provides access to Queen's research output. Every effort has been made to ensure that content in the Research Portal does not infringe any person's rights, or applicable UK laws. If you discover content in the Research Portal that you believe breaches copyright or violates any law, please contact openaccess@qub.ac.uk. 


\title{
The extra-territorial obligations of European states regarding human rights in the context of terrorism
}

\author{
Brice Dickson
}

\section{INTRODUCTION}

Constitutions are primarily inward looking, setting out rights and obligations as between a particular state and the people who are lawfully in that state. ${ }^{1}$ Sometimes they give fewer rights to non-nationals of the state, ${ }^{2}$ but more usually there is at least an implicit acceptance that the state's domestic law can extend constitutional rights to non-nationals, even when they have entered or remained in the state unlawfully. A constitution may also indicate that the state is free to enter into treaties with other states, ${ }^{3}$ the result of which can be the overlaying of constitutional rights and obligations with additional state commitments, often extending human rights protection to people who are non-nationals and unlawfully in the state. Multilateral human rights treaties usually talk, sometimes within the same document, about the rights of 'everyone', 4 'anyone', 5 'every human being', 6 'all persons', ${ }^{7}$ or 'no one'. ${ }^{8}$ Only rarely do they specify protection for the rights of 'every citizen' ${ }^{9}$ or make specific provision for 'an alien'. 10

This chapter is not concerned with the constitutional rights of non-nationals who are already lawfully living in a state, although there may well be a case for enhancing those rights, especially in the field of electoral law. ${ }^{11}$ Rather, it focuses on the growing tendency of international human rights law (IHRL) to require states to protect the rights of non-nationals who are in the state unlawfully and of nationals and non-nationals who are outside the state, especially when any of these people are involved in terrorist or counter-terrorist activity. It reviews these additional obligations within a European context, focusing on the extent to which the law of the European Union (EU law) and the law of the European Convention on Human Rights (ECHR law) require European states to abide by such obligations and drawing

\footnotetext{
${ }^{1}$ The US Constitution speaks of 'the right of the people peaceably to assemble' (Amendment I), 'the right of the people to keep and bear arms' (Amendment II) and 'the right of the people to be secure in their persons, houses, papers, and effects, against unreasonable searches and seizures' (Amendment IV). Elsewhere it speaks of 'no person' being subjected to specified treatment (Amendments V, XIV and XXII).

${ }^{2}$ At times the US Constitution speaks of 'citizens of the United States' having a right (Amendments XV, XIX, XXIV and XXVI - all of which concern the right to vote). The French Constitution provides that France 'shall ensure the equality of all citizens before the law, without distinction of origin, race or religion' (art 1). In the Declaration on the Rights of Man and of the Citizen 1789, which is incorporated into the Constitution of the Fifth French Republic of 1958 through its Preamble, some rights are conferred on 'every man' (e.g. arts 7 and 9) while others are confined to 'all citizens' (e.g. arts 6 and 14). See too Sophie Boyron, The Constitution of France: A Contextual Analysis (Oxford and Portland, Hart Publishing, 2013) Ch 6.

${ }^{3}$ E.g. art 53.1 of the French Constitution provides that 'The Republic may enter into agreements with European States which are bound by undertakings identical with its own in matters of asylum and the protection of human rights and fundamental freedoms, for the purpose of determining their respective jurisdiction as regards requests for asylum submitted to them....'.

${ }^{4}$ E.g. UN Covenant on Civil and Political Rights 1966, arts 9(1) and 12(1)-(2).

${ }^{5}$ Ibid., arts 6(4) and 9(2)-(5).

${ }^{6}$ Ibid., art. 6(1).

${ }^{7}$ Ibid., arts $10(1)$ and $14(1)$.

${ }^{8}$ Ibid., arts 8 and 12(4).

${ }^{9}$ Ibid., art 25.

${ }^{10}$ Ibid., art 13.

${ }^{11}$ Federico Fabbrini, 'Voting rights for non-citizens: the European multilevel and the US federal constitutional systems compared' (2011) 7 Eur Con LR 392; David Cole, 'Are foreign nationals entitled to the same constitutional rights as citizens?’ (2002-3) 25 Thomas Jefferson LR 367.
} 
especially on the case law of UK courts in this field. The discussion is divided into three parts, each dealing with a separate type of situation. It first considers the extent to which a European state is obliged to grant asylum to alleged terrorists on the basis that if they were refused asylum they would suffer human rights abuses in the state of which they are a national. It then examines whether, more generally (that is, outside asylum claims), a European state may be obliged not to deport or extradite an alleged terrorist to another state because he or she might suffer an abuse of human rights in that state. Finally, the chapter looks at whether a European state whose security forces are engaged in counter-terrorism activities abroad is obliged to protect the human rights of the individuals serving in those forces and/or the human rights of the alleged terrorists whom the forces are confronting.

While welcoming the extension of state responsibility which is occurring in those types of situation, the chapter notes that it is happening in a way which introduces three aspects of relativity into the protection of human rights, thereby potentially undermining the universalism of the concept. First, European law protects only some human rights extraterritorially. Second, it protects those rights only when there is 'a real risk' of their being violated. Third, in some situations it protects those rights only when there is a real risk of their being violated 'flagrantly'.

\section{THE RIGHT OF TERRORIST SUSPECTS TO BE GRANTED ASYLUM}

It must be recalled that not all international human rights documents recognise the right to be granted asylum. While it is acknowledged in the American Declaration of Human Rights of $1948,{ }^{12}$ the Universal Declaration of Human Rights of $1948,{ }^{13}$ the Inter-American Convention on Human Rights of $1969,{ }^{14}$ the African Charter of Human and People's Rights of $1981,{ }^{15}$ and the EU Charter of Fundamental Rights of $2007,{ }^{16}$ it is not mentioned in the European Convention on Human Rights of 1950 or the UN Covenant on Civil and Political Rights of 1966.

The lex specialis in this area is the UN Convention Relating to the Status of Refugees of 1951, as modified by the Additional Protocol of 1967. Article 1A(2) defines a refugee as any person who:

owing to well-founded fear of being persecuted for reasons of race, religion, nationality, membership of a particular social group or political opinion, is outside the country of his nationality and is unable, or owing to such fear, is unwilling to avail himself of the protection of that country...

But the Convention goes on to say in Article $1 \mathrm{~F}^{17}$ that it does not apply to:

any person with respect to whom there are serious grounds for considering that:

\footnotetext{
12 Article 27.

13 Article 14(1) provides: '(1) Everyone has the right to seek and to enjoy in other countries asylum from persecution. (2) This right may not be invoked in the case of prosecutions genuinely arising from non-political crimes or from acts contrary to the purposes and principles of the United Nations.'

14 Article 22(7).

${ }^{15}$ Article 12(3).

${ }^{16}$ Article 18.

17 The provisions mentioned in nn 12-15 above also contain this kind of exception, but not in such detail. Art 18 of the EU Charter cross-refers to the Refugee Convention and Protocol.
} 
(a) he has committed a crime against peace, a war crime, or a crime against humanity...

(b) he has committed a serious non-political crime outside the country of refuge prior to his admission to that country as a refugee;

(c) he has been guilty of acts contrary to the purposes and principles of the United Nations.

To date, 145 states have ratified the 1951 Convention, including nearly every state in Europe ${ }^{18}$ but not the US. There is no international court focusing on ensuring compliance with the Refugee Convention, so national courts are relatively free to interpret it in their own way. ${ }^{19}$ The Convention sets out minimum guarantees: governments may, if they wish, grant asylum in situations where they are not legally obliged to do so under the Convention.

In Europe the Refugee Convention is overlaid with even more specific legal norms. The EU began working towards a Common European Asylum System in 1999, although under the so-called Dublin Convention a common procedure was already in force to allow some EU countries to determine which state should be responsible for examining asylum applications lodged in another EU state. ${ }^{20}$ In 2003 the procedure was replaced by what became known as the Dublin II Regulation, ${ }^{21}$ recast in 2013 as the Dublin III Regulation. ${ }^{22}$ In addition the EU agreed a 'Eurodac' Regulation in 2000 (on the sharing of asylum seekers' fingerprints), ${ }^{23}$ a Reception Conditions Directive in 2003, ${ }^{24}$ a Qualification Directive in $2004,{ }^{25}$ and an Asylum Procedures Directive in 2005. ${ }^{26}$ These documents are all targeted at non-EU nationals (referred to as 'third country nationals'), the presumption being that persecution does not occur within any EU state. ${ }^{27}$ The EU's rules on asylum are to some extent a corollary to its rules on the free movement of workers ${ }^{28}$ and on the abolition of border controls; ${ }^{29}$ indeed the whole EU 'project' is premised on the assumption that EUcitizens should have greater rights than non-EU citizens.

\footnotetext{
${ }^{18}$ Andorra and San Marino have not ratified.

${ }^{19}$ See e.g. IA (Iran) v Secretary of State for the Home Dept [2014] UKSC 6, [2014] 1 WLR 384 (UK Supreme Court holding that just because the UNHCR had granted refugee status to the appellant in both Iraq and Turkey this did not mean that he was entitled to it in the UK).

${ }^{20}$ This was under the so-called Dublin Convention of 1990. For an early critical evaluation of its operation, see Agnès Hurwitz, 'The 1990 Dublin Convention: a comprehensive assessment' (1999) 11 Int J Refugee Law 646.

${ }^{21}$ Regulation 2003/343/EC. In 2006 the operation of the Dublin II Regulation was heavily criticised in a report issued jointly by the European Council on Refugees and Exiles and the European Legal Network on Asylum, available at: www.refworld.org/pdfid/47fdfacdd.pdf (accessed 18 December 2015). However the Dublin II Regulation does not per se violate the ECHR: Joanna Lenart, "“Fortress Europe": Compliance of the Dublin II Regulation with the European Convention for the Protection of Human Rights and Fundamental Freedoms' (2012) 28 Utrecht J of Int'l and Eur Law 4.

22 Regulation 2013/604/EU. This has been in force since 1 January 2014.

${ }^{23}$ Regulation 2013/603/EU, in force since 20 July 2015.

${ }^{24}$ Directive 2013/33/EU, in force since 19 July 2015.

${ }^{25}$ Directive 2004/83/EC.

${ }^{26}$ Directive 2005/85/EC. This was replaced by Directive 2013/13/EU, in force since 19 July 2015.

${ }^{27}$ For a guide to EU and ECHR law in this context, see the Fundamental Rights Agency's Handbook on European Law Relating to Asylum, Borders and Immigration (2014 edition), available at: fra.europa.eu/sites/default/files/handbook-law-asylum-migration-borders-2nded_en.pdf (accessed 18 December 2015).

${ }^{28}$ Treaty on the Functioning of the EU, art. 45.

${ }^{29}$ Under the Schengen Convention of 1990 (further implementing the Schengen Agreement of 1985). The UK and Ireland have opted out of this Convention and Bulgaria, Croatia, Cyprus and Romania have not yet fulfilled their promise to ratify it. On the other hand, three non-EU states have already agreed to comply with it (Iceland, Norway and Switzerland).
} 
Under the Dublin III Regulation, asylum seekers are supposed to be returned by the EU member state in which the asylum application is made to the EU member state where the applicant first entered the EU, but the Court of Justice of the EU (CJEU) has confirmed that states cannot simply assume that other EU states will not subject asylum seekers to inhuman or degrading treatment. In $N S$ and $M E^{30}$ the CJEU held that under Article 4 of the EU's Charter of Fundamental Rights, which is identical in wording to that of Article 3 of the ECHR, ${ }^{31}$ a member state cannot transfer an asylum seeker to the member state where that person first entered the EU if the former member state:

cannot be unaware that systemic deficiencies in the asylum procedure and in the reception conditions of asylum seekers in [the latter] Member State amount to substantial grounds for believing that the asylum seeker would face a real risk of being subjected to inhuman or degrading treatment within the meaning of that provision. ${ }^{32}$

Moreover, under the Qualification Directive, ${ }^{33}$ 'third country nationals' (that is, non-EU nationals) are excluded from refugee status if they fall within the categories mentioned in Article $1 \mathrm{~F}$ of the Refugee Convention, ${ }^{34}$ and the Directive slightly broadens the exclusion by making it explicit that 'particularly cruel actions, even if committed with an allegedly political objective, may be classified as serious non-political crime' ${ }^{35}$

For its part, the ECHR applies to 'everyone within the...jurisdiction' of any of the 47 member states of the Council of Europe, whatever their nationality. ${ }^{36}$ All 28 EU member states are also members of the Council of Europe. Whatever the position under EU law, therefore, a European state's treatment of asylum seekers, whether from EU states or from any other state in the world, can be subjected to scrutiny by the European Court of Human Rights (ECtHR) to see if it breaches Article 3 of the ECHR. The ECtHR has found Greece's asylum procedures to be in violation of Article 3 and has also held Belgium in violation of the same provision for returning an asylum seeker to Greece. ${ }^{37}$ Not only were refugees being detained in Greece in inhuman and degrading detention conditions, they were still living in such conditions after being released from detention. More generally, in NA v UK the ECtHR made it clear that an applicant for asylum does not have to show that there are special distinguishing features in his or her case, but only that 'the general situation of violence in the country of destination was of a sufficient level of intensity to create a real risk that any removal to that country would violate Article $3{ }^{3} .{ }^{38}$ If this were not so, the protection offered by Article 3 would be illusory. In Sufi and Elmi $v U K,{ }^{39}$ for example, the ECtHR found that

\footnotetext{
${ }^{30}$ NS and ME Joined Cases C-411/10 and C-493/10, [2012] 2 CMLR 9. These were requests from courts in the UK and Ireland for preliminary rulings concerning the asylum procedures used in Greece.

31 'No one shall be subjected to torture or to inhuman or degrading treatment or punishment.'

32 Note 30 above, [106].

${ }^{33}$ Note 25 above, art 12(2).

${ }^{34}$ See text at $\mathrm{n} 17$ above.

${ }^{35}$ Note 25 above, art 12(2)(b).

${ }^{36}$ ECHR, art 1 (emphasis added). The only European state not to be a member of the Council of Europe is Belarus.

${ }^{37}$ MSS v Belgium and Greece (2011) 53 EHRR 2. This decision was relied upon by the CJEU in NS and ME, n 30 above (see paras 88-91 of the judgment). It was also followed by the ECtHR in Sharifi v Italy and Greece, App No 16643/09, judgment of 21 October 2014 (available only in French). For a summary of other ECtHR cases in this field see the Court's Factsheet on 'Dublin Cases' (July 2015), available at www.echr.coe.int/Documents/FS_Dublin_ENG.pdf (accessed 18 December 2015).

38 (2009) 48 EHRR 15, a case involving Sri Lanka (emphasis added).

39 (2012) 54 EHRR 9. This decision throws into doubt the correctness of two earlier decisions by the House of Lords, in $R v$ Secretary of State for the Home Department, ex parte Adan [1999] 1 AC 293 (concerning clan
} 
the lawless condition of Somalia made it impossible to return either of the applicants to any part of that country.

The top court in the UK - formerly the Appellate Committee of the House of Lords, now the Supreme Court - has dealt with numerous asylum claims in recent years and has often adopted a generous interpretation of the Refugee Convention, regardless of the position under the ECHR. This has spilled over into cases involving alleged terrorists, as evidenced by $R$ (JS) (Sri Lanka) v Secretary of State for the Home Department, ${ }^{40}$ where the Supreme Court held that it could not be said of Sri Lanka's Tamil Tigers that they were 'predominantly terrorist in character'. This meant that a Tamil Tiger could still be granted asylum in the UK. ${ }^{41}$ On the other hand, the Supreme Court has said that the exclusion from refugee status set out in Article $1 \mathrm{~F}(\mathrm{a})$ of the Refugee Convention should not be limited to situations of 'joint criminal enterprises' but should extend to 'wider concepts of common design, such as the accomplishment of an organisation's purpose by whatever means are necessary including the commission of war crimes'. ${ }^{42}$ And in Al-Sirri v Secretary of State for the Home Department the Supreme Court held that the exclusion from refugee status provided for by Article $1 \mathrm{~F}(\mathrm{c})$ could be triggered by terrorist activity if (as stated in guidelines issued by the UN High Commissioner for Refugees) the activity 'attacks the very basis of the international community's coexistence'. ${ }^{43}$

The effect of the Refugee Convention, EU law and ECHR law is, therefore, that in Europe non-nationals are protected against the risk of suffering some human rights abuses in their home country. It is the likelihood of these abuses occurring, and their severity, which gives the individual the right to remain in the country of refuge. Within the UK a fear of persecution by criminal gangs will usually not be enough to justify the granting of asylum ${ }^{44}$ and applicants can be refused even if this means that, to avoid persecution, they will have to be returned to a part of their home country where they have never previously lived. ${ }^{45}$ Moreover, if an asylum seeker has been engaged in what a national judge views as a 'serious political crime' under Article $1 \mathrm{~F}(\mathrm{~b})$ of the Refugee Convention, it will not assist the applicant to claim that this 'crime' was in fact an act of freedom-fighting. ${ }^{46}$ Given the 'freedom fighting' that has occurred in places such as Libya, Egypt and Syria in recent years, states wishing to give refuge to any such fighters may have to do so at their discretion, not because they are obliged to do so under supra-national law.

THE RIGHT OF TERRORIST SUSPECTS NOT TO BE DEPORTED, EXTRADITED OR SUBJECTED TO SANCTIONS

warfare in Somalia) and $R$ (Hoxha) $v$ Special Adjudicator [2005] UKHL 19, [2005] 1 WLR 1063 (concerning persecution in Albania).

40 [2010] UKSC 15, [2011] 1 AC 284.

${ }^{41}$ Cf also R (Sivakumar) v Secretary of State for the Home Dept [2003] UKHL 14, [2003] 1 WLR 840 (House of Lords holding that an asylum applicant who had a fear of persecution in Sri Lanka because he was wrongly suspected of being a Tamil Tiger could claim asylum in the UK).

${ }^{42}$ R (JS) (Sri Lanka) v Secretary of State for the Home Department, n 40 above, at [38] (per Lord Brown); see too [49] (per Lord Hope DP).

43 [2012] UKSC 54, [2013] 1 AC 745, citing para 17 of 'Guidelines on International Protection: Application of Exclusion Clauses: Article 1F of the 1951 Convention relating to the Status of Refugees’ (2003).

${ }^{44}$ Horvath $v$ Secretary of State for the Home Department [2000] UKHL 38, [2001] 1 AC 489.

45 Januzi $v$ Secretary of State for the Home Department [2006] UKHL 5, [2006] 2 AC 426.

${ }^{46} T v$ Secretary of State for the Home Department [1996] AC 742 (a case concerning terrorism in Algeria). 
Deciding whether to grant refugee status to an asylum seeker is one thing. Deciding what to do with an asylum seeker who has been refused refugee status is another. ${ }^{47}$ We should also bear in mind that even if a person has been granted asylum, the Refugee Convention still permits him or her to be deprived of that status at a later stage. Article 32(1) specifically allows this 'on grounds of national security or public order'. However Article 33(1) adds a significant qualification, which is known as the rule of non-refoulement, or non-return, 'No Contracting State shall expel or return a refugee in any manner whatsoever to the frontiers of territories where his life or freedom would be threatened on account of his race, religion, nationality, membership of a particular social group or political opinion.'

Note that there is not an exact overlap between this provision and Article $1 \mathrm{~A}(2)$, in that the former applies even if there is no 'well-founded fear of being persecuted' on the given bases. The prospect of a threat can be enough to trigger the protection. Article 33(1) is also different from the specific European approach, which on the one hand limits nonrefoulement to situations where there is a real risk of harm being suffered but on the other hand extends it to cover harm that takes the form of inhuman or degrading treatment. ${ }^{48}$

Article 33(2) of the Refugee Convention qualifies the non-refoulement rule in Article 33(1) by providing that:

The benefit of the present provision may not, however, be claimed by a refugee whom there are reasonable grounds for regarding as a danger to the security of the country in which he is, or who, having been convicted by a final judgment of a particularly serious crime, constitutes a danger to the community of that country.

This too is not a replica of Article $1 \mathrm{~F}$ of the Convention, which governs the denial of refugee status in the first place. Article 33(2) is wider in that it extends to persons who have not been found guilty of any crime, but narrower in that the danger posed by the person must relate to the security or community of the country of refuge. Nevertheless, under the European approach, as we shall now see, such an exception to the rule of non-refoulement does not exist at all, since supranational courts have broadened the rule against non-refoulement so that it applies even in cases where the beneficiary is a danger to the security or community of the country. This is not always a popular stance for courts to take but, to borrow Ronald Dworkin's phrase, it is a consequence of 'taking rights seriously' ${ }^{49}$

\section{How the ECtHR has Developed Non-Refoulement}

The dilemma facing the UK government in the case of Karamjit Singh Chahal, an Indian Sikh separatist who was living legally in the UK, was that the Home Secretary wished to deport him because his presence was deemed unconducive to the public good ${ }^{50}$ but there was a risk that if he was returned to India he would be ill-treated by the police there. The UK government argued that no real risk of ill-treatment had been established but also that, even if it had, the protection afforded by Article 3 of the ECHR should not be regarded as absolute in situations where a state needs to remove a person from its territory on grounds of national security: in such cases the state should be entitled to weigh the likelihood of the asylum

\footnotetext{
${ }^{47}$ For a valuable summary of ECHR case law on deportation and extradition, see Ana Salinas de Frías, CounterTerrorism and Human Rights in the Case Law of the European Court of Human Rights (Strasbourg, Council of Europe, 2012) 73-91.

${ }^{48}$ See the previous section of this chapter.

49 Taking Rights Seriously, Harvard University Press, Cambridge MA, 1978.

${ }^{50}$ The power to deport for such a reason was conferred by the Immigration Act 1971, s. 3(5)(b).
} 
seeker being ill-treated abroad against the danger he or she poses to the host nation. But the ECtHR firmly rejected such a proposition. As the ECtHR ruled:

The prohibition provided by Article 3 against ill-treatment is equally absolute in expulsion cases. Thus, whenever substantial grounds have been shown for believing that an individual would face a real risk of being subjected to treatment contrary to Article 3 if removed to another State, the responsibility of the Contracting State to safeguard him or her against such treatment is engaged in the event of expulsion. In these circumstances, the activities of the individual in question, however undesirable or dangerous, cannot be a material consideration. The protection afforded by Article 3 is thus wider than that provided by Articles 32 and 33 of the United Nations 1951 Convention on the Status of Refugees.... ${ }^{51}$

The decision of the ECtHR thus overlays the Refugee Convention with an extra stratum of human rights protection, though not one which confers the full protection of the ECHR on all persons who may be liable to expulsion. It singles out Article 3 rights, but only in so far as there are 'substantial grounds for believing' that there is 'a real risk' that a particular individual will be subjected to ill-treatment. ${ }^{52}$ Expulsion will not be halted merely because some 'lesser' right, such as the right to free speech or the right to freedom of association, will almost certainly be violated if the person is removed to the state in question. ${ }^{53}$ Nor will it be halted if there are merely 'grounds for believing' that there is 'a risk' that ill-treatment will occur. This can be contrasted with the position adopted by the ECtHR in cases where a state is being challenged for not having taken steps to prevent the abuse of children who are within the state. In $E v U K,{ }^{54}$ for instance, a violation of Article 3 was found when authorities in the UK failed to notice that a stepfather was abusing his stepchildren. As the Court put it:

Even if the social services were not aware he was inflicting abuse at this time, they should have been aware that the children remained at potential risk. The fact that at the relevant time there was not the knowledge of the prevalence of, and persistence of, sexual offenders victimising children within a family that there exists now, is not significant in this case where, as the applicants emphasise, the social services knew that there had been incidences of sexual abuse resulting in criminal offences and were under an obligation to monitor the offender's conduct in the aftermath of the conviction. ${ }^{55}$

\footnotetext{
${ }^{51}$ Chahal v UK (1997) 23 EHRR 413, para 80. This principle was re-affirmed by the Grand Chamber of the European Court in Saadi v Italy (2009) 49 EHRR 730.

${ }^{52}$ In Soering v UK (1989) 11 EHRR 439 the Strasbourg Court applied the same principle to art 2 rights (a case on extraditing a person to the US, where he would have been at risk of a death sentence). Worryingly, in Finogenov v Russia App Nos 18299/03 and 27311/03, judgment of 6 March 2012 (the Moscow theatre hostage case) the ECtHR was prepared to grant the Russian authorities a margin of appreciation so far as the military and technical aspects of the situation were concerned (para 213). See Stephen Skinner, 'Deference, proportionality and the margin of appreciation in lethal force case law under Article 2 of the ECHR' [2014] EHRLR 32.

${ }^{53}$ This is not to say that the CJEU and ECtHR do not protect the exercise of free speech abroad. The US Supreme Court's decision in USAID v Alliance for Open Society 122 S Ct 2321 (2013), discussed by Su in Chapter X of this book, should be compared with Society for the Protection of Unborn Children $v$ Grogan C159/90 [1991] 3 CMLR 849 (CJEU) and Open Door Counselling and Dublin Well Woman Centre v Ireland (1992) 15 EHRR 244 (ECtHR).

${ }^{54}$ (2003) 36 EHRR 31.

${ }^{55}$ Ibid., para 96.
} 
While the two situations are not wholly analogous, it is indisputable that in European states Article 3 rights are vindicated more easily when a child is at risk within the state than when an alleged terrorist is at risk outside the state. In other words, even though the ECtHR has interpreted the ECHR in a way which goes beyond the Refugee Convention, it still grants less protection to potential deportees or extraditees than it does to persons who have a right to remain in the state. A degree of relativity has thus been introduced even though Article 3 is meant to confer an absolute right. ${ }^{56}$ In a recent inadmissibility decision the European Court held that a suspected terrorist, whom the Court had previously ruled could not be deported to Libya for fear of being ill-treated there, ${ }^{57}$ could not complain that the order excluding him from the Netherlands had not been lifted. ${ }^{58}$

For states, such as the UK, which do not baulk at extraditing their own nationals, this differential treatment extends even to extradition. Under the Extradition Act 2003 a court must not authorize a person's extradition if it would violate that person's Convention rights. ${ }^{59}$ This has not prevented the Parliamentary Joint Committee on Human Rights from reporting that the provisions in question 'do not, in practice, offer adequate human rights protection for those subject to proceedings', because 'the courts have set their interpretation of the threshold for extradition to be refused on human rights grounds too high'. ${ }^{60}$ In Babar Ahmad $v$ UK the ECtHR held that it would not breach the human rights of the radical cleric Abu Hamza, or those of other applicants, to extradite them to the US where they were at risk of being imprisoned in a 'supermax' prison and held in solitary confinement. ${ }^{61}$ As Mavronicola and Messineo have pointed out, ${ }^{62}$ this decision calls into question the commitment of the ECtHR to the absoluteness of the right not to be subjected to ill-treatment.

\section{Memoranda of Understanding}

After the bombs in London on 7/7 2005, when the government was planning how to take more effective counter-terrorism measures, Prime Minister Tony Blair cited Chahal $v$ UK as an obstacle which needed to be overcome:

[W]e are today signalling a new approach to deportation orders. Let no one be in any doubt. The rules of the game are changing...Up to now, the concern has been that orders for deportation will be struck down as contrary to Article 3 of the ECHR as interpreted by the European Court in the Chahal case in 1996....However, the circumstances of our national security have now self-evidently changed and we believe we can get the necessary assurances from the countries to which we will return the deportees, against their being subject to torture or ill-treatment contrary to Article $3 .^{63}$

The legality of these 'diplomatic assurances', or Memoranda of Understanding, has been considered both in domestic courts and in Strasbourg, one of the leading cases being

\footnotetext{
${ }^{56}$ On relativity within art 3 case law more generally, see Michael Addo and Nicholas Grief, 'Does Article 3 of the European Convention on Human Rights enshrine absolute rights? (1998) 9 EJIL 510.

${ }^{57}$ A $v$ The Netherlands App No 4900/06, judgment of 20 July 2010.

${ }^{58}$ A $v$ The Netherlands (2014) 58 EHRR SE8.

${ }^{59}$ Extradition Act 2003, ss 21 and 87.

60 The Human Rights Implications of UK Extradition Policy, 15th Report of the Joint Committee, 2010-12, HL 156 / HC 522, para 71.

${ }^{61}$ App Nos 24027/07 et al, judgment of 10 April 2012. Babar Ahmad was later sentenced to $12 \frac{1}{2}$ years in a US prison: www.bbc.co.uk/news/uk-28335976 (accessed 18 December 2015).

62 'Relatively absolute? The undermining of Article 3 ECHR in Ahmad v UK' (2013) 76 MLR 589.

${ }^{63}$ www.theguardian.com/politics/2005/aug/05/uksecurity.terrorism1 (accessed 18 December 2015).
} 
that which involved the radical Islamic cleric Abu Qatada. ${ }^{64}$ The House of Lords ruled unanimously that the Memorandum which had been agreed with the Jordanian government (whereby if Abu Qatada were returned to Jordan the authorities there would ensure that he would not be ill-treated) was enough to satisfy the ECHR. They applied the test which they had developed in $R$ (Ullah) $v$ Special Adjudicator, ${ }^{65}$ namely that the violation of any right other than those conferred by Articles 2 and 3 would need to be serious, flagrant, gross or fundamental. ${ }^{66}$ As Lord Phillips, the President of the Supreme Court, put it:

Before the deportation of an alien will be capable of violating Article 6 there must be substantial grounds for believing that there is a real risk (i) that there will be a fundamental breach of the principles of a fair trial guaranteed by Article 6 and (ii) that this failure will lead to a miscarriage of justice that itself constitutes a flagrant violation of the victim's fundamental rights. ${ }^{67}$

The House of Lords was genuinely trying to predict what the ECtHR would say about such a Memorandum based on that Court's own previous pronouncements, but it failed to anticipate the new stand about to be embraced by the ECtHR. When the case reached Strasbourg the seven judges agreed with the Law Lords' approach to what constitutes a 'flagrant denial of justice' but differed from them as regards the test to be applied when determining the risk of such a violation occurring. The House of Lords had held that the applicant needed to prove on a balance of probabilities that torture-tainted evidence would be admitted at his trial in Jordan, ${ }^{68}$ whereas the ECtHR held that the applicant merely had to adduce evidence capable of proving that there were grounds for believing that he would be exposed to 'a real risk' of such evidence being admitted (for example, through someone else having been tortured). ${ }^{69}$ This was the first time the ECtHR had held that an applicant's Article 6 rights would be violated if he or she were removed to a country outside Europe. Later the British Home Secretary was able to renegotiate the Memorandum with Jordan in a

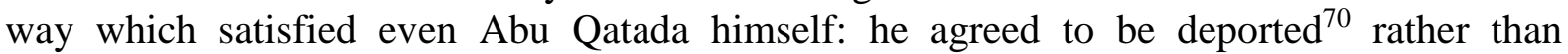
continue his fight through the British and European courts. In 2014 Abu Qatada was acquitted by a court in Jordan and released from custody. ${ }^{71}$

The net result, again, is that the ECtHR is prepared to protect some but not all of the Convention rights of terrorist suspects. Moreover, when considering potential violations of the right to fair trial outside Europe they are prepared to protect defendants only against 'fundamental' or 'flagrant' violations. The ECtHR has not specified what would amount to a less serious and therefore ignorable violation. This is another blow to the universal character

\footnotetext{
${ }^{64}$ But see also Saadi v Italy (2009) 49 EHRR 30; Müslim v Turkey (2006) 42 EHRR 16; Labsi v Slovakia App No 33809/08, judgment of 15 May 2012; and Shamayev v Georgia and Russia App No 36378/02, judgment of 12 April 2005. See generally Salinas de Frías, n 47 above, 79-82 and 88-91.

65 [2004] UKHL 26, [2004] 2 AC 323.

66 Ibid., paras 18 and 24 (Lord Bingham), para 50 (Lord Steyn) and para 70 (Lord Carswell).

${ }^{67}$ RB (Algeria) v Secretary of State for the Home Dept [2009] UKHL 10, [2009] 2 AC 110, para 141.

68 This was consistent with the attitude struck by the majority of the nine Law Lords in Av Secretary of State for the Home Dept (No 2) [2005] UKHL 71, [2006] 2 AC 221 (the so-called second Belmarsh case).

${ }^{69}$ Othman v UK (2012) 55 EHRR 1. For comments see Lucian Bojin, 'Challenges facing the European Court of Human Rights: fragmentation of the international order, division in Europe and the right of individual petition’ in Spyridon Flogaitis, Tom Zwart and Julie Fraser (eds), The European Court of Human Rights and Its Discontents: Turning Criticism into Strength (Edward Elgar Publishing, Cheltenham and Northampton MA, 2013) 54-8.

70 See www.channel4.com/news/abu-qatada-will-leave-uk-voluntarily-after-treaty (accessed 18 December 2015).

71 See www.theguardian.com/world/2014/sep/24/abu-qatada-cleared-terror-charges-jordan-court (accessed 18 December 2015).
} 
of human rights, but we should not be too surprised at the willingness of the ECtHR to adopt a relativist approach. It lives in the world of Realpolitik and is conscious of the need to respect long-established principles of public international law which have not yet been infiltrated by IHRL. This was made obvious in the Court's recent judgment in Jones $v U K^{72}$ where, by six to one, a Chamber held that the doctrine of sovereign immunity still trumps the Article 6 right of access to justice in situations where victims of torture wish to sue a foreign state or its officials in respect of their ill-treatment. Thus, while Europe will not remove a person to any country where evidence derived from torture might be used in court as evidence against that person, it will not insist on a victim of torture being allowed to claim compensation within Europe from the authorities of a non-European state in which he or she was tortured. The concept of an effective remedy, guaranteed by Article 13 of the ECHR, still plays second fiddle to the doctrine of sovereign immunity.

\section{THE DUTIES AND RIGHTS OF SECURITY FORCES ENGAGED IN COUNTER- TERRORISM OPERATIONS ABROAD}

As already alluded to, Article 1 of the ECHR requires each of the 47 member states of the Council of Europe to secure the Convention rights of 'everyone within their jurisdiction'. The beneficiaries do not need to be nationals of those states. If the Convention rights of a nonnational are not protected to the same extent as those of a national, the non-national can potentially claim that his or her right to freedom from discrimination has been violated: Article 14 lists 'national or social origin' as well as 'association with a national minority' as prohibited bases for discriminating between people in the enjoyment of their rights. ${ }^{73}$

In recent years the ECtHR has developed its jurisprudence on what 'within their jurisdiction' means in Article 1. The effect has been to expand the applicability of the Convention overseas. As a result of the ECtHR's judgments in cases such as Bankovic $v$ Belgium $^{74}$ and Al-Skeini $v$ UK, ${ }^{75}$ the Convention allows victims of ill-treatment, or the families of victims who have been killed, to seek redress against Council of Europe states which are in 'effective control' of the territory in which the ill-treatment or death occurred. We have learned that such control can exist not only over a consulate or a detention centre but over an entire region of a foreign country. As the Grand Chamber put it in Al-Skeini:

The obligation to secure, in [an area under effective control], the rights and freedoms set out in the Convention, derives from the fact of such control, whether it be exercised directly, through the Contracting state's own armed forces, or through a subordinate local administration....The fact that the local administration survives as a result of the contracting state's military and other support entails that state's responsibility for its policies and actions. The controlling state has the responsibility under Article 1 to secure, within the area under its control, the entire range of substantive rights set out in the Convention and those additional Protocols which it has ratified. It will be liable for any violations of those rights. ${ }^{76}$

\footnotetext{
${ }^{72}$ App No 34356/06, judgment of 14 January 2014. On 2 June 2014 a Panel of the Grand Chamber rejected a request to have the Chamber's judgment referred to the Grand Chamber.

${ }^{73}$ Protocol 12 to the ECHR confers additional rights to be free from discrimination, but to date only 14 states have ratified it (and not the UK).

${ }^{74}$ (2007) 44 EHRR SE5. For a devastating critique of this decision see Erik Roxstrom, Mark Gibney and Terju Einarsen, 'The NATO bombing case (Bankovic et al $v$ Belgium et al) and the limits of Western human rights protection' (2005) 23 Boston Univ Int'l LJ 55.

75 (2011) 53 EHRR 18.

${ }^{76}$ Ibid., para. 138, citing, amongst other sources, Cyprus v Turkey (2002) 35 EHRR 30.
} 
This is indeed a bold, some might say unrealistic, assertion, but it is largely mirrored by the views expressed by the International Court of Justice on the inter-relationship between IHRL and international humanitarian law (IHL) in its Advisory Opinion in the Legal Consequences of the Construction of a Wall in the Occupied Palestinian Territory (2004) and its judgment in Democratic Republic of Congo v Uganda (2005). ${ }^{77}$

However, in extending the extra-territoriality of the ECHR the Court in Al-Skeini departed from the approach it had adopted in Bankovic regarding the set of rights which must be protected if the ECHR is to be applied extra-territorially. In Bankovic the Grand Chamber preferred an all-or-nothing approach: the ECHR could not be 'divided and tailored' ${ }^{78}$ But in Al-Skeini the Grand Chamber said:

It is clear that, whenever the State, through its agents, exercises control and authority over an individual, and thus jurisdiction, the State is under an obligation under Article 1 to secure to that individual the rights and freedoms under Section I of the Convention that are relevant to the situation of that individual. In this sense, therefore, the Convention rights can be "divided and tailored". ${ }^{79}$

The ECtHR has not yet gone so far as to hold that members of a state's armed forces can themselves claim the protection of the ECHR when they are engaged in military operations abroad. This was also the view of the UK Supreme Court in $R$ (Smith) $v$ Oxfordshire Assistant Deputy Coroner, ${ }^{80}$ where the mother of a soldier who had died of heatstroke while serving at a British military base in Iraq was able to persuade only three of the nine Supreme Court justices who heard her appeal that her son was within the jurisdiction of the UK at the time of his death. However in a later case, involving a different family named Smith, as well as other families, the Supreme Court ruled unanimously that at the time of their deaths, when they were blown up by improvised explosive devices while travelling in Land Rovers in Iraq, two British soldiers were within the UK's jurisdiction for the purposes of the ECHR. ${ }^{81}$ The Supreme Court went on to hold by four-to-three that the claims that not enough had been done to protect the soldiers should not be struck out on the ground that they were not within the scope of Article 2 of the Convention. ${ }^{82}$ It is surely only a matter of time before the ECtHR will have to rule on whether a state's soldiers have rights under the ECHR even when they are in the theatre of war.

The immediate question which these developments raise is whether IHRL is beginning to displace IHL in this context. ${ }^{83}$ The Al-Skeini case related to operations in Iraq. Even though the operations occurred after the fall of the Sadaam regime, they were events

\footnotetext{
${ }^{77}$ Legal Consequences of the Construction of a Wall in the Occupied Palestinian Territory, Advisory Opinion of 9 July 2004, available at www.icj-cij.org/docket/index.php?p1=3\&p2=4\&case=131\&p3=4 (accessed 18 December 2015); Case Concerning Armed Activities on the Territory of the Congo (Democratic Republic of the Congo v Uganda), judgment of 19 December 2005, available at www.icj-cij.org/docket/files/116/10455.pdf (accessed 18 December 2015). Both cases were relied upon by the Grand Chamber in Al-Skeini v UK, ibid., paras 90-91.

${ }^{78}$ Note 74 , para 75.

${ }^{79}$ Note 75, para 137. It would seem that in this field ECHR law is in advance of US law: see Chapters 10 and 12 by Daskal and Hafetz respectively in this book.

${ }^{80}$ [2010] UKSC 29, [2011] 1 AC 1. The three dissenters were Lady Hale, Lord Mance and Lord Kerr.

${ }^{81}$ Smith $v$ Ministry of Defence [2013] UKSC 41, [2-14] AC 52.

82 The majority comprised Lord Hope, Lord Walker, Lady Hale and Lord Kerr; the dissenters were Lord Mance, Lord Wilson and Lord Carnwath.

${ }^{83}$ See e.g. Clive Walker, 'Detention in extremis: transferring lessons from counter-terrorism policing to military detentions' in Aniceto Masferrer and Clive Walker (eds), Counter-terrorism, Human Rights and the Rule of Law: Crossing Legal Boundaries in Defence of the State (Edward Elgar Publishing, Cheltenham and Northampton MA, 2013) 268-74.
} 
within an international armed conflict because occupying coalition forces were still fighting armed insurgents. Arguably, the Geneva Conventions on the laws of war should have applied as the lex specialis. Yet the ECtHR was content to apply IHRL in addition to IHL. While most human rights activists would doubtless applaud the usurpation of IHL by IHRL in this context (and perhaps in others), because for the most part the latter's protections are more protective than the former's, we are surely entitled to know exactly when and to what extent IHRL applies. To date the ECtHR has been singularly uninformative on that front. This lack of clarity persists even though the Court has very recently had an opportunity to state more precisely how the ECHR interacts with IHL during international armed conflicts, especially in the context of the right to liberty under Article 5 of the ECHR. In Hassan $v U K,{ }^{84}$ which concerned the detention of a man in Iraq by UK forces, the ECtHR had to consider whether Article 5(1) should be interpreted as being impliedly qualified by the broader detention powers granted to states under the Third ${ }^{85}$ and Fourth ${ }^{86}$ Geneva Conventions. Holding that it should, the Court added that the right to habeas corpus conferred by Article 5(4) of the ECHR could be supplanted by the forms of review provided for under the Fourth Geneva Convention. ${ }^{87}$ While there are positive dimensions to this judgment, it leaves many questions unanswered. ${ }^{88}$

\section{CONCLUSION}

In various situations EU law and ECHR law have been striving to extend the obligations on European states to protect suspected terrorists against human rights violations in countries outside Europe. First, in the context of claims for asylum the CJEU and the ECtHR have superimposed obligations already established by the Refugee Convention of 1951. They have done this not so much by adopting a new definition of persecution, the key term within the Refugee Convention, but by accepting that asylum seekers must not be sent back to states where they are at real risk of suffering death, ill-treatment or loss of liberty. However, real risks of other human rights violations will not prevent the denial of asylum. Secondly, and relatedly, in situations where a state is considering whether to deport or extradite a person (whether or not he or she is an asylum-seeker), the two European courts have made it abundantly clear that the principle of non-refoulement enshrined in Article 32 of the Refugee Convention, and qualified by Article 33 of the same Convention, has been supplemented by the principle that no one can be removed to a jurisdiction where there is a real risk that he or she might be killed, inhumanely or degradingly treated or arbitrarily deprived of liberty. This is laudable, but it does tend to confirm the hierarchy of rights which is apparent in the context of asylum claims. The ECtHR will prevent deportation or extradition in instances where other rights might be violated only if there is a real risk of a 'flagrant' or 'fundamental' violation of the right in question. Thirdly, the ECtHR has recently significantly expanded the espace européen by holding that member states of the Council of Europe take the ECHR with them

\footnotetext{
${ }^{84}$ App 29750/09, judgment of 16 September 2014 (GC).

${ }^{85}$ Geneva Convention Relative to the Treatment of Prisoners of War, 12 August 1949, especially arts 4 and $12-$ 16.

${ }^{86}$ Geneva Convention Relative to the Protection of Civilian Persons in Time of War, 12 August 1949, especially arts $76-135$.

${ }^{87}$ Article 78. The Third Geneva Convention contains no provision requiring a review of the legality of the internment of combatants.

${ }^{88}$ See e.g. Lawrence Hill-Cawthorne, 'The Grand Chamber judgment in Hassan $v$ UK' at www.ejiltalk.org/thegrand-chamber-judgment-in-hassan-v-uk (accessed 18 December 2015); Diane Webber, 'Hassan v United Kingdom: a new approach to security detention in armed conflict?' at www.asil.org/insights/volume/19/issue/7/hassan-v-united-kingdom-new-approach-security-detention-armedconflict (accessed 18 December 2015).
} 
when they exercise effective control of a person or a location in another state. This has meant that individuals living in places such as Iraq and Afghanistan have been able to rely upon the ECHR when European troops have violated their rights there. Again, though, it is only some violations which qualify for this protection: the ECtHR has accepted the reality that temporary control over an individual does not usually lend itself to full and faithful implementation of the whole of the ECHR. This is appropriate, for the perfect should not be the enemy of the good. It is likely that similar protection will soon be accorded by the ECtHR to members of the security forces of European nations when they are operating extraterritorially.

Europe is therefore protecting people more than ever against violations of their rights which might occur in other states, including states which are not members of the Council of Europe. But it is doing so in a selective manner and a by-product of the approach may be an impression that some people deserve greater protection of their human rights than others. Any such impression is a reflection of the fact that we live in a world of nation states, where there is only so much that one state can do to prevent human rights violations occurring in another state. Just because all human rights cannot be protected does not mean that none should be. Accusations of double standards are accordingly unjustified. The primary onus is on the governments of states where violations of rights occur to both prevent them and remedy them. 